University of Nebraska - Lincoln

DigitalCommons@University of Nebraska - Lincoln

Faculty Publications, UNL Libraries

Libraries at University of Nebraska-Lincoln

$1-1-2000$

Catalog design, catalog maintenance, catalog governance

Mary K. Bolin

University of Nebraska--Lincoln, mbolin2@unl.edu

Follow this and additional works at: https://digitalcommons.unl.edu/libraryscience

Part of the Library and Information Science Commons

Bolin, Mary K., "Catalog design, catalog maintenance, catalog governance" (2000). Faculty Publications, UNL Libraries. 50.

https://digitalcommons.unl.edu/libraryscience/50

This Article is brought to you for free and open access by the Libraries at University of Nebraska-Lincoln at DigitalCommons@University of Nebraska - Lincoln. It has been accepted for inclusion in Faculty Publications, UNL Libraries by an authorized administrator of DigitalCommons@University of Nebraska - Lincoln. 
Published in Library Collections, Acquisitions, \& Technical Services 24 (2000) 53-63

\title{
Catalog design, catalog maintenance, catalog governance
}

\author{
Mary K. Bolin
}

\begin{abstract}
The design of library catalogs and the maintenance of their contents equals catalog governance, that is, professional responsibility for the catalog. The design of library catalogs and their contents are an example of the standards that are the hallmark of modern librarianship. Although design and maintenance standards have always had an array of participants, in recent years the participants in catalog design and maintenance have become more numerous and varied, and therefore its governance has become more diffuse. Although the card catalog had a standard form in which design and maintenance were linked, that is not true of today's OPAC in which the same content can take many different forms. Emerging standards, such as SGML, may actually provide a general solution in which OPACs have various, customized forms based on standard content and in which catalog librarians encode, maintain, and interpret the standard data and help guide the discussion of options for design. This article discusses the past and present governance of library catalog design and maintenance and explores issues in a "programmatic" model of governance for the catalog.
\end{abstract}

Keywords: Cataloging; OPAC design; Database maintenance; Library governance

\section{Introduction}

Since at least the last quarter of the 19th century, librarians in the modern Anglo-American tradition have been developing standards for access to information. The design of library catalogs and their contents are an example of such standards. The invention of the card cata$\log$ and the creation of descriptive cataloging codes yielded a standard form and standard contents. Taken together, the design of the catalog and the maintenance of its contents equal

Copyright (C) 2000 Elsevier Science Ltd. Used by permission 
catalog governance, i.e., professional responsibility for the catalog. Although design and maintenance standards have always been developed by an array of participants, including library associations, national libraries, vendors, and so on, in recent years the participants in catalog design and maintenance have become more numerous and varied, and therefore its governance has become more diffuse. Moreover, although the card catalog had a standard form in which design and maintenance were linked, that is not true of today's OPAC in which the same content can take many different forms. Although some catalog librarians, in particular, may feel sidelined by the diffuse governance of the maturing OPAC, emerging standards, such as SGML, may actually provide a general solution in which OPACs have various, customized forms based on standard content and in which catalog librarians encode, maintain, and interpret the standard data and help guide the discussion of options for design. This article discusses the past and present governance of library catalog design and maintenance and explores issues in a "programmatic" model of governance for the catalog.

\section{Design, maintenance, governance}

Fewer than 20 years ago, an important part of library school cataloging curriculum was learning to create catalog cards. Part of learning to catalog was learning how the content of a bibliographic record was formatted into the catalog card display. At that same time, libraries were joining OCLC and other bibliographic utilities and using them as a source of cataloging records and catalog cards. Even as OPACs and integrated library systems began to be developed and acquired by more and more libraries during the 1970s and 1980s, many libraries viewed databases, such as OCLC, primarily as a source of catalog records that would produce catalog cards. An important part of learning to use OCLC was learning the library's "card profile" - correctly formatting call numbers, ordering the right number of cards, and so on.

Once cards were acquired, they were "loaded" into the catalog by opening a drawer and inserting the card in the correct place. This involved learning a set of filing rules, which went beyond mere alphabetical order. In many libraries, filing was done by one group of people and "revised" by another group, to ensure accuracy. Corrections, updates, replacements, and other changes to cards were accomplished by creating a whole new set of cards or by pulling a card or cards and making corrections by one of a number of methods. Cards were constantly being pulled, corrected, and re-filed, even as cards for new items were being added to the catalog.

Typing cards was certainly tedious and time-consuming. Particularly for those with no interest in cataloging, the idea of prescribed punctuation, spacing, indention, and so on, may seem arbitrary or even ridiculous. As archaic as the technique may seem, however, this scene from a Barbara Pym novel was an example of giving the content of a bibliographic record a standard form. The format of catalog cards had a design that was agreed on and recognized. The onerous process of acquiring or producing cards, filing them, pulling them for update or correction, then plying the electric eraser or the proper color of correction fluid, making corrections and re-filing are all part of catalog maintenance, the way in which information gets into the catalog and is maintained and corrected. 
Put catalog design and catalog maintenance together and they equal catalog governance, professional responsibility for the catalog. Governance can be thought of as a combination of concerns that combine economics and other, similar administrative concerns with the theoretical, scholarly, and exploratory approach of the professional in any field. The paradigm of librarianship described by Veaner, in which "everything is assigned and nothing is assigned" depicts a kind of governance in which librarians have what he termed "programmatic responsibilities" and "programmatic leadership," which demands that librarians be able to think subtly, tolerate ambiguity, and take responsibility for something that is not a "list of tasks" [1] but is a program. Libraries have used various organizational structures, including traditional hierarchical, departmental organizations; collegial organizations that combine the functional arrangement with the academic faculty model of governance; as well as team or matrix models that attempt to overcome the problems associated with highly specialized departmental organizations. The governance of the catalog is carried out within whatever model of governance is in place in the library as a whole.

The governance of the catalog demands the kind of programmatic governance that Veaner described. Programmatic governance of the catalog can be looked at in at least two ways. In one view, local practice is paramount, and the ability of catalog librarians to autonomously create a catalog that serves the needs of local patrons is viewed as the ideal. In a second view, one that is arguably preferable and more realistic, catalog librarians exercise programmatic governance by articulating standards for catalog design and maintenance that have been developed by the international library community, by taking a broad view of cataloging that can take account of new technology and new forms of information and can see themselves as working not just in a single library setting, but as part of a scholarly network whose product is used by people across the street, across the country, across the ocean, and so forth. In this view of governance, catalog librarians make a range of contributions to a system whose governance is shared with public services librarians, vendors, other libraries in a consortium, and so on. At the same time, this broader view of shared governance does not preclude services tailored to the needs of a particular community of users, nor does it demand a literal-minded or slavish view of adhering to a standard. Programmatic governance does not dictate any particular outcome, and this article does not do so either. The desirability of operating creatively, confidently, and assertively in a dynamic environment does not demand that the result be a catalog with a particular interface, nor that the result even be a "catalog" as we would now define it. The autonomy implied by this programmatic view of governance is not without its checks and balances. The "program" that Veaner described is analogous to the degree programs in academic departments. The academic freedom enjoyed by the faculty who govern these programs co-exists with the actions of legislatures, citizens, students, administrators, accrediting agencies, and so on, as well as with market pressures of various kinds.

Design, maintenance, and governance of the catalog have changed in the last 20 years. Although automated library systems are powerful, and certainly easier to maintain than card catalogs, the design of today's catalog is divorced from its maintenance, and therefore the governance role once played by catalog librarians has been split among system vendors, programmers, and librarians, some of whom may be catalog librarians. 


\section{Discussion of catalog design}

There have been a number of interesting studies on catalog design. Wool [2] compared OPAC displays for a group of bibliographic records and found a certain consensus in layout and labeling. Cherry et al. [3] and Kopak and Cherry [4] are similar studies of how the content of MARC records takes form in various OPACs. Wool et al. [5] addressed both design and maintenance: the "machine translation" of MARC records into OPAC displays, i.e., the transformation of MARC data from a bibliographic utility into a record in an online catalog. This process of loading, and thereby indexing and organizing records, is analogous to filing in a card catalog and has ambiguities, complexities, and choices that can be compared to the intricacies of filing rules.

Those studies looked at MARC records as the underpinning for an OPAC and examined how MARC fields are displayed, how they are labeled, and what fields are indexed for retrieval. McDonough [6] and Wool [7] looked beyond MARC to other forms of metadata, such as SGML tagging, and the consideration of MARC as an SGML application. Similarly, Caplan and Guenther [8] considered how the fields defined by MARC format can interact with the Dublin Core metadata elements in the cataloging of Internet resources.

Other discussions of catalog design and maintenance issues include debate over specific format features (e.g., labels vs. card format vs. something else), a standard design for OPACs versus the desire to customize, and an ongoing question about the future usefulness of MARC format as a basis for OPAC records. The topic of the future of libraries, cataloging, and catalogers continues to be debated and includes themes, such as the nar ve and narrow view of cataloging and catalogers held by some administrators, the present and future capabilities of technology, and the roles played by catalog librarians in their organizations (The archives of the Autocat discussion group contain many lively and thoughtprovoking discussions of all these issues at http://listserv.acsu.buffalo.edu/archives/autocat. html.). One question that is implicit in informal, professional discussions, as well as in the published literature on the topic, is whether there should be a prescriptive standard for OPAC display versus a general solution that can lead to many display outcomes. MARC and SGML have the potential to provide such a general solution, by semantic encoding of the contents of a record, i.e., telling what things are rather than what they should look like.

\section{The evolution of design, maintenance, and governance}

The history of modern librarianship is the history of standards, of their development, and their adoption. Standards have included things as seemingly mundane as the standard dimensions of the catalog card and standard catalog trays to hold it, descriptive cataloging codes from Cutter [9] to AACR2 [10]; standards for subject access, such as the LC classification and subject headings; standards for electronic encoding and access, such as MARC format [11]; international standards, such as NISO's standard for information retrieval protocols, Z39.50 [12]; document description languages, such as SGML [13]; OCLC's Dublin Core metadata standard [14]; and so on. One thing these standards have in common is that they have been developed by an array of participants from commercial vendors to 
librarians to national and international agencies with the common goal of improving access to information.

Although the development of standards for information storage and retrieval is one of our most significant accomplishments, most librarians probably still feel the tension that exists between adhering to a standard and customizing service to meet the local needs of the library. This tension is nothing new, and it illustrates the two aspects of governance, which are the desire for local autonomy and the participation in a broader professional endeavor. Ideally, a standard should be able to satisfy both the local and the more global need. Moreover, once adopted, no standard lasts forever, and in fact, standards grow out of the expressed needs of the community of users.

The card catalog had a standard design that followed the prescriptions of the descriptive cataloging rules in force at the time that each record was created. The design of the catalog was an explicit part of the standard for descriptive cataloging, and design and maintenance were inextricably tied together. Participants in governance included the larger library community, whose agencies and representatives were responsible for developing descriptive cataloging rules; library administrations, who had fiscal authority and made decisions about how resources were distributed; and catalog librarians, who had the professional obligation to serve patrons by implementing a shared standard for design (creating the cards) and maintenance (filing according to one of a number of shared standards, correcting, and updating).

Another participant in the governance of card catalogs was also one of the participants in the creation of the design and maintenance standard. The tension between adhering to a standard and the perceived need or desire for some local practice emerged early, when LC began selling its printed cards in 1901. The availability of a source for cataloging records relieved some of the burden of creating cataloging information for each item acquired by the library. At the same time, it forced libraries to adhere to LC practice, which went beyond simply using the same set of cataloging rules. The use of LC cards is an early example of the model of governance in which catalog librarians adopt a standard, perhaps with both pragmatic and visionary motives, and in which the economic concerns of administrators can interact with the programmatic responsibilities of catalog librarians. The conflict between the two views of governance - local versus more global — can also be seen here. Catalog librarians can easily see the need for efficiency and the need to take advantage of laborsaving methods, but the desire to avoid reinventing the wheel conflicts at times with our desire for professional autonomy, in other words, our desire for a localized governance. Although LC cards were a tremendous boon to catalog design and maintenance, and although the quest for LC records and the desire to do it like LC does it is strong, accepting catalog records from LC means accepting its decisions about analyzing or tracing series, about whether an item is a new manifestation, and accepting subject headings whether they reflect emerging topics and disciplines or not. Especially in a card catalog environment, the motivation to tailor LC records to local customs and needs was strong.

This article is anything but a paean to the lost golden days of the card catalog. Revolutionary in its day, the card catalog was " 'down' twenty-four hours a day” in Michael Gorman's famous remark, and was onerous to maintain. Although it was constructed according to a shared standard, standards change, sometimes radically. In the early 1980 s a new 
cataloging code was imposed on existing card catalogs. The implementation of AACR2 was awkward, labor-intensive, and hard to accomplish in a satisfying way in a card catalog, where the solutions ranged from interfiling differing headings, making hundreds of new cross references, or pulling and correcting thousands of cards. Moreover, although the format of the card catalog was standard, it gave a very limited amount of information about each item. As for governance, almost from the beginning librarians had to share that with LC, whose dual role was as a vendor of cataloging information and as a leader in the development and implementation of standards. Although catalog librarians certainly had governance responsibilities for the accepted design and the ongoing maintenance of the card catalog, public services librarians were, no doubt, justifiably frustrated by the limitations of the card catalog and by the reluctance of catalog librarians to make enrichments to the standard record.

\section{Online cataloging}

Before the online catalog became widespread in libraries, there was online cataloging. For about the first 10 years of its existence as a bibliographic utility, OCLC was probably seen by many or most catalog librarians primarily as a source of catalog cards, even as we began to undertake retrospective conversion and as we devised procedures that took into account how we would eventually use our electronic records to bring up an online catalog. The participants in the governance of the catalog continued to be the community that produced cataloging codes and standards; along with library administrators and catalog librarians; and vendors, such as OCLC, who purveyed cataloging records from LC and others.

The tension between local practice and adhering to a standard was probably exacerbated by using OCLC. Although it took some effort to change an LC card, an OCLC record could be easily altered, not only to fix actual errors, but to suit any kind of local preference before the cards were produced. Along with setting up a card profile to suit the library's preferences, editing OCLC records was a way of locally retaining design and maintenance, and therefore governance, responsibility. The fact that many records in the OCLC database are from sources other than LC introduced a new factor, however. Although using LC cards had been one stage in sharing governance responsibility for the data in the catalog, the possibility of shared cataloging in a common database was a giant step beyond that. Truly sharing cataloging, accepting cataloging done at any one of hundreds of OCLC member libraries, even if it promised speed and efficiency, was a change in governance that many catalog librarians found hard to accept. Sometimes there was good reason for this. In the early days of OCLC, the quality of records varied widely. The strategies that libraries developed to deal with that variation were ways of retaining local governance over the design and maintenance of the catalog.

\section{Early OPACs}

The earliest OPACs developed during the time that libraries were also joining bibliographic utilities. These early systems often took one of two forms: they were either 
circulation or acquisitions systems that may have used something other than MARC as the basis for their records, or they were MARC-based catalogs, perhaps with circulation, serials, and acquisitions information. In either case, the display was often card-like, with labels and searches that mimicked the appearance and access points of a card catalog. In contrast to the card catalog, there was no standard for OPAC design, although those that loaded MARC records began with data created according to a standard. These early systems often had one feature that the card catalog lacked: keyword searching, which allowed random access to the contents of bibliographic records, rather than requiring users to know in which order elements appeared.

During this era, a new kind of specialty was emerging, and during the 1980s many libraries created the position of systems or automation librarian. This phenomenon had governance implications for catalog librarians. For the first time, the design and maintenance of catalogs was separated, although the design ultimately may have been based on the MARC record and/or the format of the catalog card. Governance of the catalog at this point was shared by vendors, systems librarians, administrators, as well as catalog librarians and the community of those responsible for shared standards. Moreover, it was common for libraries that acquired OPACs during this era to continue maintaining a card catalog as well. The contrast between the crudest early OPACs and the resources going into card catalog maintenance led to unfounded predictions of the demise of catalogers and cataloging codes.

Maintaining a programmatic governance over the catalog in the face of hopeful, but unrealistic, expectations of what technology can do has been a problem for catalogers at least since that time.

\section{Mature OPACs}

As library systems matured in the late 1980s and into the 1990s, and as more and more libraries acquired or invented systems that included an OPAC, circulation, serials, and acquisitions modules, bibliographic data began to be used not just to identify what the library owned, but to track orders, check out material, give detailed location and holdings information, and so on. There was still no clear standard for OPAC design, although standards for query language and similar areas had begun to emerge. The governance implications of the integration of bibliographic and other types of information are obvious. The catalog was no longer something that literally stood apart from other files in the library. Bibliographic information was beginning to be integrated with order, fund accounting, inventory, and circulation data. Changes made to a record could affect not just the catalog but other kinds of records as well, ordering or fund information, for example. This integration of functions and information into one system gave more people a stake in design, maintenance, and governance of what was no longer just "the catalog." Participants included all those who were involved up until this time, but to these were added librarians from other functional areas, such as reference, acquisitions, and circulation.

At the same time, both vendors and systems librarians were taking on increased responsibility for both design and maintenance. The limits of the system; the designers' understanding of bibliographic data and of the traditional functions of the library catalog; and economic 
considerations, such as memory and disk space, all played their part in design; maintenance; and, therefore, in governance, of automated systems of which the catalog was a part.

Many libraries found themselves in consortium arrangements at this time as well, in which groups of libraries joined together to acquire an automated system, sharing responsibility for purchase and maintenance of the system. The economic and resource-sharing advantages of forming consortia for the purpose of acquiring an automated library system made this practice increasingly common as library systems matured during the 1980s and 1990s. The advantages are undeniable: strength in numbers for negotiating with vendors, the sensible sharing of mainframe computers and computer personnel, and so on. Nevertheless, the consortium arrangement exacerbates the weakening of local governance seen in the automation process in general. Decisions about loading and maintaining records have to be made by multiple libraries, and communication to vendors and programmers about priorities and problems can be more difficult when more than one library is involved.

It is at this point that questions of design, maintenance, and governance become acute. As OPACs mature, our expectations of them go up. As library systems were maturing, so were personal computers, and so were the computer skills of catalog librarians and of librarians in general. Ten years ago, our concerns were likely to be finishing retrospective conversion, choosing and acquiring a system, barcoding the collection, considering how to phase out what remained of the card catalog, and so on. With those activities finished, we expect to have a system that is functional, elegant, seamless, and reliable. Moreover, after years of working with MARC data, catalog librarians expect a system that exploits the richness of the MARC format; the encoding that goes far beyond traditional (and important) card catalog elements, such as "author" and "title," to less obvious collocations, such as the instrumentation of a musical composition; searches by format; retrieval by standard numbers; and so on.

What we often have instead of the elegant system we envision is something that seems to have taken the MARC data and produced something bland and oversimplified, that does little to exploit the capabilities of MARC format. At worst, these mature library systems have "features" that cannot be changed or corrected by any catalog librarian or systems librarian, but only by the vendor, who may have little interest in doing so. At this stage of OPAC design, there is a sort of bureaucratic distance between librarians, system vendors, and their programmers. Programmers struggle to understand the requests of each library and try to program solutions to each problem or situation.

\section{Web sites and Web catalogs}

The catalog is just one part of most integrated library systems, which generally contain not only circulation and acquisitions data, but also access to other databases, such as periodical indexes. The inclusion of these other databases integrates tools that have always been acquired from a publisher, but are now part of a menu along with the library's catalog. As with printed indexes, maintenance responsibility for these other databases rests not with the library but with the publisher. At the same time, library users now have access to the catalogs of hundreds of other libraries, either as part of a menu from their own library system

or by searching the Internet. As more catalogs are becoming available through the Internet, 
many library systems are also developing Web-based interfaces. These Web-based catalogs form part of the Web sites that are being almost universally developed by individual libraries, which provide an array of information sources, including the catalog, other databases, guides to the library's organization and services, lists of Internet resources, and so on.

Catalog librarians may regard the library Web site with ambivalence. There is no standard for the creation of these Web sites. This lack of standardization can be seen as liberating for individual libraries, who can create a site tailored to the needs of their patrons, and there is certainly local governance of these locally created sites. However, the very ease of creating a Web site, even if it is often a well-planned, high-quality site, makes it easy for the catalog to be subsumed into an array of menus, links, and lists. At this point, system vendors and public services librarians have a more active role in design and maintenance of the system, with the role of catalog librarians remaining static or dwindling. Governance becomes more diffuse, and the declining prominence of the catalog as a product leads once more to naïve predictions of the end of cataloging and catalogers.

\section{New standards}

At the same time, new standards for catalog design and maintenance are emerging, and they are being promulgated by the same participants that we have come to expect in these endeavors: the library community as represented by national and international agencies, and prominent vendors, such as OCLC. These emerging standards include, for example, the SGML Document Type Definition (DTD) for MARC records being developed by LC [15], which brings together two encoding systems (MARC and SGML) that have many similarities. OCLC's Dublin Core Metadata Initiative [14] is another emerging standard that attempts to bring the philosophy of cataloging to the construction and control of Internet files and sites by proposing a core of metadata fields to be applied to impose a standard for identifying and retrieving Internet items. Similarly, the Cataloging Committee: Description and Access of the Association for Library Collections and Technical Services of the American Library Association report on metadata [16] describes work being done to examine existing cataloging codes and standards in light of the need for enriched and accessible Internet sites. Finally, in an effort to apply the principles of bibliographic control to the design and governance of the catalog, the Task Force on Guidelines for OPAC Displays of the Division of Bibliographic Control of the International Federation of Library Associations and Institutions (IFLA) has produced a report, written by Martha Yee for the Task Force, that proposes a "corpus of good practice" for OPAC indexing and display [17]. All of these projects use the traditions of bibliographic control and the knowledge of catalog librarians

to improve description of and access to information for users through shared standards.

\section{The future}

Before considering the future, perhaps this is the time to evaluate the past and present. Although the shortcomings of automated systems and the place of the library catalog as just 
one line on a menu of hundreds of items may be frustrating to catalog librarians, it would be ridiculous to be nostalgic for any previous era. The days when the catalog stood alone and was maintained solely by catalogers were not the good old days. Card catalog maintenance is burdensome and tedious. The days of the early OPAC and the transition from card catalogs to online catalogs were the days when library patrons and employees got used to looking in at least two places for everything. Even dealing with the most recalcitrant vendor of a mature library system has results that are infinitely preferable to any aspect of card catalog maintenance or to maintaining both a card and online catalog.

Although we may feel we could do better and participate more, even the present situation is better than any time in the past. Who would not trade the power of the Internet and of a local Web-based catalog plus hundreds more at one's fingertips for the autonomy and control that catalogers supposedly once had? In fact, a look back at the participants in catalog design, maintenance, and governance shows that catalog librarians have shared governance of the catalog at least since LC cards went on sale in 1901, and more likely since the emergence of modern cataloging codes a quarter of a century before that. Adopting a standard and acquiring a product from a vendor require a broader view of governance than the preferences of one group of catalogers or library patrons. The evolution that has brought us in the last 100 years to the present situation, in which the catalog is part of a much larger library Web site or digital library, is the product of a century of governance increasingly shared and increasingly programmatic, in which cataloging and the catalog do not stand alone. Not only is governance increasingly shared, governance is also not the same thing as "control." Although we may be fond of concepts such as "authority control," "bibliographic control," and so on, governance of today's catalog does not equal absolute control of the catalog. This implies tolerating some measure of ambiguity and even chaos.

In the next generation of library systems that is beginning to emerge now, rather than trying to program solutions to individual problems, an approach based on SGML, or something similarly general, could create a "universal loader" for MARC records that could help libraries achieve a model of catalog governance that synthesizes local control with governance by a broader professional community. Despite criticisms of the limitations of MARC, it has not yet had its true power exploited. Like SGML, MARC features "semantic tagging" of what fields are rather than what they should look like in any display. Work by OCLC on a standard for metadata and by LC on a DTD for MARC shows that the governance of the catalog continues to be shared by vendors, government agencies, and the entire community of librarians. Once again, standards will provide the answer, not by prescribing the way data should be displayed, but by encoding meaning in a standard way, and catalog librarians have more than 100 years of expertise at that kind of encoding. More than ever, there is potential for truly programmatic governance of the catalog that is at once local and universal.

\section{References}

[1] Veaner AB. Paradigm lost, paradigm regained? A persistent personnel issue in academic librarianship, II. Coll Res Libr 1994;55:389-403. 
[2] Wool G. The many faces of a catalog record: a snapshot of bibliographic display practices for monographs in online catalogs. Inform Technol Libr 1996;15:173-95.

[3] Cherry JM. Bibliographic displays in OPACS and web catalogs: how well do they comply with display guidelines? Inform Technol Libraries 1998;17:124 -37. Cherry JM, Wi liamson NJ, Gu Z. OPACS in twelve Canadian academic libraries: an evaluation of functional capabilities and interface features. Inform Technol Libr 1994;13:174 -95.

[4] Kopak RW, Cherry JM. Bibliographic displays and Web catalogues: user evaluations of three prototype displays. Electr Libr 1998;16:309-24.

[5] Wool GJ, Austhof B, Breckbill A. Cataloging standards and machine translation: a study of reformatted ISBD records in an online catalog. Inform Technol Libr 1993;12:383- 403.

[6] McDonough JP. SGML and the USMARC standard: applying markup to bibliographic data. Tech Serv Q 1998;15:21-33.

[7] Wool G. A meditation on metadata. Serials Librar 1998;33:167-78.

[8] Caplan P, Guenther R. Metadata for Internet resources: the Dublin core metadata elements set and its mapping to USMARC. Catalog Classif Q 1996;22:43-58.

[9] Cutter CA. Rules for a dictionary catalog, 4th edition (rewritten). Washington, DC: GPO, 1904. (US Bureau of Education. Special report on public libraries, part II. First issued as part 2 of the 1876 Special Report; 2nd edition, 1889; 3rd edition, 1891.

[10] ALA. Anglo-American cataloguing rules. Chicago, IL: American Library Association, 1998.

[11] MARC 21 format for bibliographic data: including guidelines for content designation, 1999 edition. Washington, D.C.: Library of Congress, Cataloging Distribution Service, 1999.

[12] National Information Standards Organization (US). Information retrieval (Z39.50): application service definition and protocol specification: an American national standard. Bethesda, MD: NISO Press, c1995.

[13] National Institute of Standards and Technology (US). Standard generalized markup language (SGML). Gaithersburg, MD: US Dept. of Commerce, National Institute of Standards and Technology. Springfield, VA, 1988. For sale by the National Technical Information Service, Federal information processing standards publication-FIPS publication 152.

[14] OCLC. Dublin core metadata initiative. http://www.oclc.org/oclc/research/projects/core/index. htm, July 19, 1999.

[15] Library of Congress Network Development, and MARC Standards Office. MARC DTDs (document type definitions). http://lcweb.loc.gov/marc/marcsgml.html, July 19, 1999.

[16] Association for Library Collections Technical Services. Cataloging and Classification Section. Committee on Cataloging. Description and Access. Task Force on Metadata. Summary report. http://www.ala.org/alcts/ organization/ccs/ccda/tf-meta3.html, July 19, 1999.

[17] International Federation of Library Associations and Institutions. Section on Cataloguing. Task Force on Guidelines for OPAC Displays of the IFLA Division of Bibliographic Control. Worldwide review of "guidelines for OPAC displays." http://www.ifla.org/ifla/VII/s13/guide/opac. htm, July 19, 1999. 